\title{
Determination of Optimal Storage Condition for Pre-packed Hanwoo Loin
}

\author{
Kuk-Hwan Seol ${ }^{1}$, Tu San Park' ${ }^{2}$ Mi-Hwa Oh${ }^{1}$, Beom-Young Park ${ }^{1}$, Seong In $\mathrm{Cho}^{2}$, and Mooha Lee* \\ School of Agriculture, Adama Science \& Technology University, Asella, Ethiopia \\ ${ }^{1}$ National Institute of Animal Science, Rural Development Administration, Suwon 441-706, Korea \\ ${ }^{2}$ Department of Biosystems \& Biomaterials Science and Engineering \& Research Institute \\ for Agriculture and Life Sciences, Seoul National University, Seoul 151-921, Korea
}

\begin{abstract}
The aim of this study was to determine the optimal storage condition of pre-packed Hanwoo beef without freezing. Hanwoo loin was purchased from a local distributor at $48 \mathrm{~h}$ after slaughter, then sliced in $1.5 \pm 0.5 \mathrm{~cm}$ thickness, and packed in a polyethylene (PE) tray covered with linear low-density polyethylene (LLDPE) film. The studied factors to set the optimal storage condition were chamber temperature $\left(5,2.5\right.$ and $-1{ }^{\circ} \mathrm{C}$ for $\left.14 \mathrm{~d}\right)$, cooling method (direct and indirect cooling system), and ultraviolet (UV) light irradiation for beef surface sterilization $(0,30,60$, and $120 \mathrm{~min})$. The changes of $\mathrm{pH}$, thiobarbituric acid reactive substances (TBARS) and number of aerobic bacteria were measured during storage. Beef samples stored in $-1^{\circ} \mathrm{C}$ showed the minimal increasing rate in TBARS and microbial growth. After $15 \mathrm{~d}$ of storage, there was no significant difference in $\mathrm{pH}$ and TBARS values. However, the microbial population of beef stored in direct type cooling chamber $(4.25 \pm 0.66 \mathrm{Log}$ CFU/g) was significantly lower than that of beef stored in indirect type chamber $(6.47 \pm 0.08 \mathrm{Log}$ CFU/g) $(p<0.05)$. After $4 \mathrm{~d}$ of storage, 60 or $120 \mathrm{~min}$ UV light irradiated beef samples showed significantly lower microbial population, and at $14 \mathrm{~d}$ of storage, $60 \mathrm{~min} \mathrm{UV}$ irradiated beef sample showed significantly lower microbial population (3.14 $\pm 0.43 \mathrm{Log}$ CFU/g) than control (4.46 $\pm 0.13 \mathrm{Log}$ CFU/g) $(p<0.05)$. However, TBARS values of 60 or $120 \mathrm{~min}$ UV light irradiated beef samples were significantly higher than non-irradiated beef sample after $4 \mathrm{~d}$ of storage $(p<0.05)$.
\end{abstract}

Key words: pre-packed Hanwoo beef, storage condition, aerobic bacteria, lipid oxidation

\section{Introduction}

As meat products are good media for microorganisms and easy to be perished, those are stored practically in freezer to maintain eatable state as long as possible. The advantage of freezing rather than chilling is extension of meat storage time. However, unfortunately, freezing is not recommended as the best storage method for preserving its quality. Some researches have introduced freezing and thawing increase tenderness by tissue weakening (Shanks et al., 2002; Wheeler et al., 1990). However, as the weakness is from cell and tissue damage by large ice crystals formed both intra- and inter-cellularly when frozen (Raheliæ and Pauè, 1985), it leads to weight loss which was directly related to loss of juiciness, consequently. On the aspect of sensory quality, sensory evaluation result was introduced as chilled beef had higher

*Corresponding author: Mooha Lee, P. O. Bax 193, School of Agriculture, Adama Science \& Technology University, Asella, Ethiopia. Tel: 251-22-331-4835, Fax: 251-22-331-3430, E-mail: michae181348@gmail.com acceptability in meat taste, juiciness and tenderness from panels (Lagerstedt et al, 2008). However, meat would not last more than a week in eatable state when it was stored in refrigerator to preserve sensory quality. Color change of muscle and fat with generated off-odors as a result of microbial growth and enzymatic degradation of protein and fat during chilled storage are very evident compare to freezing. Likewise, storage of both freezing and chilling has advantages and disadvantages. Storage temperature is the most important and critical factor on chilled meat quality. Physicochemical factors profile against storage temperature is difficult to describe on numerical formation for many variables affection. However, maintaining lowest temperature of chilling range in fixed temperature is the best storage method for quality preservation (Ayres, 2007; Dransfield et al, 1980; Jung et al, 1996).

The aim of this study was to set the optimal condition for the storage of pre-packed beef for consumers without freezing. Storage temperature, cooling method of chamber (direct or indirect cooling), and UV irradiation conditions for microbial sterilization in storage chamber were investigated by measuring the change of the population of 
aerobic bacteria and lipid oxidation during storage period.

\section{Materials and Methods}

\section{Preparation of samples}

Hanwoo loin was taken from grade 1 carcass after measuring the carcass grading scores by Korean beef grading standards. Selected meat was purchased from local distributor at $48 \mathrm{~h}$ after slaughter, then transported to laboratory and sliced in $1.5 \pm 0.5 \mathrm{~cm}$ thickness and packed in packed in a polyethylene tray (PE) covered with linear low density polyethylene (LLDPE) film. Pre-packed Hanwoo loin was stored in a chamber for analysis. To determine the best storage temperature, samples were stored at 3 different temperature conditions $\left(5,2.5,-1^{\circ} \mathrm{C}\right)$ for $14 \mathrm{~d}$ and physicochemical properties were analyzed. Direct- and indirect-refrigerator were controlled to the same temperature $\left(-1^{\circ} \mathrm{C}\right)$ with samples stored to verify the effect of cooling method on beef storage and to decide cooling method for better storage. Samples were taken 4 times during $15 \mathrm{~d}$ of storage and analyzed. Samples were divided into 4 groups and stored at $-1^{\circ} \mathrm{C}$, then ultraviolet ray was irradiated on each group for $0,30,60$, and 120 min at initial storage to analyze the effect on microbial sterilization. Samples were taken 4 times during $14 \mathrm{~d}$ of storage and analyzed.

\section{Preparation of cooling chambers}

Two types of temperature controllable test-refrigerator were prepared to determine the most effective factors for beef storage, such as temperature, cooling method, and irradiation condition of ultraviolet ray at initial storage. Those were indirect cooling refrigerator, which generates low temperature air and circulates into storage chamber, and direct cooling refrigerator, which circulate refrigerant into metal pipe attached on storage chamber outer wall to cool the chamber wall. They had $40 \mathrm{~L}$ volume with two vertically installed ultraviolet radiation lamps of 253.7 $\mathrm{nm}$ wavelengths with $32 \mu \mathrm{W} / \mathrm{cm}^{2}$ intensity.

\section{Physicochemical and microbial analysis on samples} $\mathrm{pH}$ of pre-packed Hanwoo loin was determined with digital $\mathrm{pH}$ meter (4 Star, Orion, USA) equipped with a combined glass electrode. Five $g$ of meat was homogenized with $20 \mathrm{~mL}$ distilled water using Ultra-Turrex T25 tissue homogenizer (Janke and Kenkel, IKA, Labor Tecnik, Germany) for $1 \mathrm{~min}$. The lipid oxidation of prepacked Hanwoo loin was measured by modified thiobarbituric acid method (Witte et al. 1970). Briefly, $5 \mathrm{~g}$ of meat sample was added to $45 \mathrm{~mL}$ of $20 \%$ trichloroacetic acid (in $2 \mathrm{M}$ phosphate solution) and homogenized using Ultra-Turrex T25 tissue homogenizer (Janke and Kenkel, IKA, Labor Tecnik, Germany), and the solution was filtered through Whatman No. 1 filter paper. After mixing $5 \mathrm{~mL}$ of filtrate with $5 \mathrm{~mL}$ of 2-thiobarbituric acid $(0.005$ $\mathrm{M}$ in water) in test tube, the test tube was kept at room temperature in the dark for $15 \mathrm{~h}$, and measured the absorbance at $531 \mathrm{~nm}$ using spectrophotometer (X-ma 1000, Human Co., Korea). Total microbial count was examined with modified standard plate count as follows; $5 \mathrm{~g}$ of sample were added to $45 \mathrm{~mL}$ of $1 \%$ sterilized buffered peptone water and homogenized with BagMixer (Interscience, France) and diluted to proper ratio. After dilution, $1 \mathrm{~mL}$ of sample was put on $3 \mathrm{M}$ petrifilm (3M, USA) and incubated at $37^{\circ} \mathrm{C}$ for $48 \mathrm{~h}$.

\section{Statistical analysis}

Whole experiments were replicated 3 times with 2 observations per each replication. Statistical analysis was performed with the SAS program for Window V9.1 (SAS Institute, USA). General linear model (GLM) with Duncan's multiple range test was carried out to analyze the significant differences among the treatments $(p<0.05)$.

\section{Results and Discussion}

\section{Effect of storage temperature on the shelf life of Hanwoo loin}

The change of physicochemical and microbial properties of Hanwoo loin stored in different temperature was shown in Table 1. There was significant difference between beef samples stored in different temperatures and storage period, however, it did not showed a consistent tendency. As confirmed by Pearson et al. (1983), TBA assay is the most popular method of measuring oxidative deterioration of lipids, and it is highly correlated with sensory evaluation scores in meat products (Igene and Pearson, 1979). All of the samples showed increasing tendency in TBARS values as the storage period increased. Above all, at $1 \mathrm{~d}$ of storage, beef samples stored in $-1^{\circ} \mathrm{C}$ showed significantly high TBARS value of $0.19 \pm 0.04 \mathrm{mg}$ malonaldehyde $/ \mathrm{kg}$ meat, however, at the end of storage $(14 \mathrm{~d})$ it was lower than other beef samples stored in 5 or 2.5 chamber. This result was corresponded with Xu et al. (2011), which reported that TBARS values of different samples were highly dependent on storage temperature. The population of aerobic bacteria in beef samples was measured during $14 \mathrm{~d}$ of storage in 3 different tempera- 
Table 1. The change of physicochemical and microbial properties of Hanwoo loin stored in cooling chambers with different temperature

\begin{tabular}{|c|c|c|c|c|c|}
\hline \multicolumn{2}{|c|}{ Storage (d) } & $\overline{11}$ & 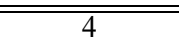 & 7 & 14 \\
\hline \multirow{3}{*}{$\mathrm{pH}$} & $5^{\circ} \mathrm{C}$ & $5.65 \pm 0.19^{\mathrm{aA}}$ & $5.57 \pm 0.01^{\mathrm{bAB}}$ & $5.62 \pm 0.02^{\mathrm{aAB}}$ & $5.53 \pm 0.02^{\mathrm{bB}}$ \\
\hline & $2.5^{\circ} \mathrm{C}$ & $5.58 \pm 0.04^{\mathrm{bB}}$ & $5.52 \pm 0.01^{\mathrm{cC}}$ & $5.56 \pm 0.03^{\mathrm{bBC}}$ & $5.65 \pm 0.01^{\mathrm{aA}}$ \\
\hline & $-1^{\circ} \mathrm{C}$ & $5.69 \pm 0.16^{\mathrm{aA}}$ & $5.61 \pm 0.04^{\mathrm{aB}}$ & $5.60 \pm 0.07^{\mathrm{abB}}$ & $5.58 \pm 0.09^{\mathrm{abB}}$ \\
\hline \multirow{3}{*}{ TBARS* } & $5^{\circ} \mathrm{C}$ & $0.13 \pm 0.04^{\mathrm{bB}}$ & $0.19 \pm 0.02^{\mathrm{B}}$ & $0.16 \pm 0.01^{\mathrm{B}}$ & $0.39 \pm 0.01^{\mathrm{abA}}$ \\
\hline & $2.5^{\circ} \mathrm{C}$ & $0.18 \pm 0.01^{\mathrm{aB}}$ & $0.17 \pm 0.03^{\mathrm{B}}$ & $0.15 \pm 0.07^{\mathrm{B}}$ & $0.43 \pm 0.04^{\mathrm{aA}}$ \\
\hline & $-1^{\circ} \mathrm{C}$ & $0.19 \pm 0.04^{\mathrm{aB}}$ & $0.17 \pm 0.06^{\mathrm{B}}$ & $0.15 \pm 0.07^{\mathrm{B}}$ & $0.35 \pm 0.04^{\mathrm{bA}}$ \\
\hline \multirow{3}{*}{ Total Microbes** } & $5^{\circ} \mathrm{C}$ & $1.52 \pm 1.14^{\mathrm{abC}}$ & $2.42 \pm 0.15^{\mathrm{aB}}$ & $2.68 \pm 0.49^{\mathrm{abB}}$ & $3.62 \pm 0.35^{\mathrm{bA}}$ \\
\hline & $2.5^{\circ} \mathrm{C}$ & $1.17 \pm 0.24^{\mathrm{bD}}$ & $1.62 \pm 0.23^{\mathrm{bC}}$ & $3.28 \pm 0.19^{\mathrm{aB}}$ & $4.35 \pm 0.22^{\mathrm{aA}}$ \\
\hline & $-1^{\circ} \mathrm{C}$ & $2.09 \pm 0.54^{\mathrm{aAB}}$ & $1.64 \pm 0.74^{\mathrm{bB}}$ & $2.27 \pm 0.75^{\mathrm{bA}}$ & $1.94 \pm 0.57^{\mathrm{cAB}}$ \\
\hline
\end{tabular}

Values are mean \pm SD

*TBARS; thiobarbituric acid reactive substances (mg malonaldehyde/kg meat)

**Total Microbes; Log CFU/g

${ }^{\mathrm{a}-\mathrm{c}}$ Means in the same column with different letters are significantly different $(p<0.05)$.

${ }^{\text {A-D }}$ Means in the same row with different letters are significantly different $(p<0.05)$.

tures. The bacterial growth rate of samples stored in each temperature has shown different characteristic since $7 \mathrm{~d}$ of storage as shown on Table 1 . The microbial count which started from 1.52, 1.17, and 2.09 Log CFU/g at the initial state increased to $3.62,4.35$, and $1.94 \mathrm{Log} \mathrm{CFU} / \mathrm{g}$ at $14 \mathrm{~d}$ of storage in $5^{\circ} \mathrm{C}, 2.5^{\circ} \mathrm{C}$ and $-1{ }^{\circ} \mathrm{C}$ conditions, respectively. By controlling storage temperature in $-1^{\circ} \mathrm{C}$ the microbial growth could be inhibited effectively. As freezing temperature of beef was introduced as $-1.8^{\circ} \mathrm{C}$ (Desrosier, 1970; Geankoplis, 1998; Singh and Heldman, 2001) and considering tolerance of temperature control, the most effective temperature was considered as $-1 \pm 0.5^{\circ} \mathrm{C}$.

\section{Effect of cooling method on the shelf life of Han- woo loin}

The change of $\mathrm{pH}$, TBARS and population of aerobic bacteria was measured during storage for $15 \mathrm{~d}$ in $-1 \pm 0.5^{\circ} \mathrm{C}$ with different cooling type chamber to define more effective cooling method. There was no significant effect of cooling type of chamber on $\mathrm{pH}$ and TBARS values dur- ing storage period (Table 2). However, there was significant difference on microbial growth rate $(p<0.05)$. The population of aerobic bacteria of beef samples stored in indirect cooling chamber showed fast growth rate than direct cooling chamber. Initial population of bacteria started from 3.18 $\pm 0.44 \mathrm{Log}$ CFU/g and resulted to $6.47 \pm$ 0.08 and $4.25 \pm 0.66 \mathrm{Log} \mathrm{CFU} / \mathrm{g}$ at the end of examination for indirect and direct cooling, respectively. From this result, direct cooling type chamber was considered as more effective than indirect cooling type chamber for inhibition of microbial growth.

\section{Effect of ultraviolet light irradiation on the shelf life of Hanwoo loin}

Effects of ultraviolet (UV) light irradiation at the initial storage of beef samples on physicochemical and microbial properties were measured to verify effectiveness on prolongation of shelf-life of Hanwoo beef stored in $-1^{\circ} \mathrm{C}$ direct cooling type chamber. There was no consistent tendency of UV light irradiation on $\mathrm{pH}$ of beef samples dur-

Table 2. The change of physicochemical and microbial properties of Hanwoo loin stored in $-1^{\circ} \mathrm{C}$ cooling chambers with different cooling type

\begin{tabular}{|c|c|c|c|c|c|}
\hline \multicolumn{2}{|c|}{ Storage (d) } & 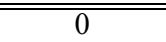 & $\overline{77}$ & 12 & 15 \\
\hline \multirow{2}{*}{$\mathrm{pH}$} & Direct & $5.60 \pm 0.13^{\mathrm{B}}$ & $5.63 \pm 0.10^{\mathrm{bB}}$ & $5.11 \pm 0.48^{\mathrm{C}}$ & $5.91 \pm 0.08^{\mathrm{A}}$ \\
\hline & Indirect & $5.60 \pm 0.13^{\mathrm{C}}$ & $5.76 \pm 0.14^{\mathrm{aB}}$ & $4.99 \pm 0.05^{\mathrm{D}}$ & $5.90 \pm 0.03^{\mathrm{A}}$ \\
\hline \multirow{2}{*}{ TBARS* } & Direct & $0.03 \pm 0.01^{\mathrm{D}}$ & $0.48 \pm 0.10^{\mathrm{C}}$ & $0.68 \pm 0.01^{\mathrm{B}}$ & $0.85 \pm 0.16^{\mathrm{A}}$ \\
\hline & Indirect & $0.03 \pm 0.01^{\mathrm{C}}$ & $0.48 \pm 0.04^{\mathrm{B}}$ & $0.79 \pm 0.17^{\mathrm{A}}$ & $0.86 \pm 0.13^{\mathrm{A}}$ \\
\hline \multirow{2}{*}{ Total Microbes** } & Direct & $3.18 \pm 0.44^{\mathrm{B}}$ & $3.43 \pm 0.79^{\mathrm{bB}}$ & $3.58 \pm 0.43^{\mathrm{bB}}$ & $4.25 \pm 0.66^{\mathrm{aA}}$ \\
\hline & Indirect & $3.18 \pm 0.44^{\mathrm{C}}$ & $4.54 \pm 0.15^{\mathrm{aB}}$ & $6.32 \pm 0.21^{\mathrm{aA}}$ & $6.47 \pm 0.08^{\mathrm{aA}}$ \\
\hline
\end{tabular}

Values are mean \pm SD

*TBARS; thiobarbituric acid reactive substances (mg malonaldehyde/kg meat)

**Total Microbes; Log CFU

${ }^{\mathrm{a}-\mathrm{b}}$ Means in the same column with different letters are significantly different $(p<0.05)$.

${ }^{\text {A-D }}$ Means in the same row with different letters are significantly different $(p<0.05)$. 
Table 3. The change of physicochemical and microbial properties of Hanwoo loin stored in $-1^{\circ} \mathrm{C}$ cooling chambers with different ultraviolet light irradiation time

\begin{tabular}{|c|c|c|c|c|c|}
\hline \multicolumn{2}{|c|}{ Storage $(\mathrm{d})$} & 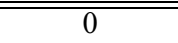 & 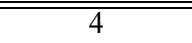 & $\overline{77}$ & $\overline{14}$ \\
\hline \multirow{4}{*}{$\mathrm{pH}$} & Control & $5.46 \pm 0.08^{\mathrm{bB}}$ & $5.46 \pm 0.06^{\mathrm{abB}}$ & $5.53 \pm 0.02^{\mathrm{aA}}$ & $5.52 \pm 0.02^{\mathrm{AB}}$ \\
\hline & UV30 & $5.53 \pm 0.03^{\mathrm{aA}}$ & $5.51 \pm 0.01^{\mathrm{aA}}$ & $5.48 \pm 0.04^{\mathrm{bB}}$ & $5.48 \pm 0.01^{\mathrm{B}}$ \\
\hline & UV60 & $5.49 \pm 0.03^{\mathrm{abA}}$ & $5.44 \pm 0.03^{\mathrm{bB}}$ & $5.43 \pm 0.01^{\mathrm{cB}}$ & $5.48 \pm 0.02^{\mathrm{A}}$ \\
\hline & UV120 & $5.41 \pm 0.07^{\mathrm{cC}}$ & $5.47 \pm 0.05^{\mathrm{abAB}}$ & $5.44 \pm 0.06^{\mathrm{bcBC}}$ & $5.48 \pm 0.05^{\mathrm{A}}$ \\
\hline \multirow{4}{*}{ TBARS* } & Control & $0.07 \pm 0.02^{\mathrm{C}}$ & $0.08 \pm 0.01^{\mathrm{bBC}}$ & $0.16 \pm 0.02^{\mathrm{bA}}$ & $0.13 \pm 0.02^{\mathrm{bAB}}$ \\
\hline & UV30 & $0.12 \pm 0.02^{\mathrm{B}}$ & $0.11 \pm 0.03^{\mathrm{bB}}$ & $0.15 \pm 0.03^{\mathrm{bB}}$ & $0.24 \pm 0.05^{\mathrm{bA}}$ \\
\hline & UV60 & $0.08 \pm 0.03^{\mathrm{C}}$ & $0.25 \pm 0.01^{\mathrm{aBC}}$ & $0.42 \pm 0.04^{\mathrm{aB}}$ & $0.84 \pm 0.04^{\mathrm{aA}}$ \\
\hline & UV120 & $0.11 \pm 0.07^{\mathrm{C}}$ & $0.21 \pm 0.06^{\mathrm{aBC}}$ & $0.34 \pm 0.10^{\mathrm{aB}}$ & $0.87 \pm 0.19^{\mathrm{aA}}$ \\
\hline \multirow{4}{*}{$\begin{array}{c}\text { Total } \\
\text { Microbes** }\end{array}$} & Control & $3.06 \pm 0.86^{\mathrm{abc}}$ & $3.30 \pm 0.31^{\mathrm{aC}}$ & $3.46 \pm 0.29^{\mathrm{aC}}$ & $4.46 \pm 0.13^{\mathrm{aB}}$ \\
\hline & UV30 & $3.29 \pm 0.64^{\mathrm{aC}}$ & $2.79 \pm 0.17^{\mathrm{bD}}$ & $3.45 \pm 0.17^{\mathrm{aC}}$ & $4.41 \pm 0.21^{\mathrm{aB}}$ \\
\hline & UV60 & $2.96 \pm 0.52^{\mathrm{abB}}$ & $2.53 \pm 0.08^{\mathrm{bC}}$ & $2.52 \pm 0.16^{\mathrm{cC}}$ & $3.14 \pm 0.43^{\mathrm{bB}}$ \\
\hline & UV120 & $2.43 \pm 0.34^{\mathrm{bC}}$ & $2.57 \pm 0.51^{\mathrm{bC}}$ & $3.02 \pm 0.54^{\mathrm{bB}}$ & $3.51 \pm 0.96^{\mathrm{bA}}$ \\
\hline
\end{tabular}

Values are mean \pm SD

*TBARS; thiobarbituric acid reactive substances (mg malonaldehyde $/ \mathrm{kg}$ meat)

**Total Microbes; Log CFU/g

${ }^{\mathrm{a}-\mathrm{c}}$ Means in the same column with different letters are significantly different $(p<0.05)$.

${ }^{A-C}$ Means in the same row with different letters are significantly different $(p<0.05)$.

ing storage (Table 3). As irradiation time was increased, the microbial growth rate was decreased. After $4 \mathrm{~d}$ of storage, 60 or 120 min UV light irradiated beef samples showed significantly lower microbial population, and at $14 \mathrm{~d}$ of storage, 60 min UV light irradiated beef sample showed significantly lower microbial population $(3.14 \pm 0.43 \mathrm{Log}$ $\mathrm{CFU} / \mathrm{g})$ than control $(4.46 \pm 0.13 \mathrm{Log} \mathrm{CFU} / \mathrm{g})(p<0.05)$. Although, UV irradiation decreased the microbial growth rate, TBARS values of UV light irradiated samples increased faster than non-irradiated control. After $4 \mathrm{~d}$ of storage, TBARS values of 60 or $120 \mathrm{~min}$ UV light irradiated beef samples were significantly higher than other beef samples $(p<0.05)$, however, $30 \mathrm{~min}$ UV light irradiated beef sample had no significant difference during all storage period ( $p>0.05)$. This counter effect is due to the UV light irradiation, which breaks the composition of fat and produce radicals, and finally acidification accrues to increase TBARS value.

\section{Conclusion}

For the prolongation of shelf life of pre-packed beef, control of storage temperature and decrease of initial population of microbes were important. Keeping the temperature just above of freezing point of beef was helpful in decreasing microbial growth rate. Direct cooling type chamber, same as Kim-chi specialized refrigerator, was more effective than indirect cooling chamber (home-style refrigerator). However, there is a need for the development of sterilization techniques for pre-packed beef without any counter effect.

\section{References}

1. Ayres, J. C. (2007) Temperature relationships and some other characteristics of the microbial flora developing on refrigerated beef. J. Food Sci. 25, 1-18.

2. Desrosier N.W. (1970) The technology of food preservation. The AVI Publishing company Inc., Connecticut. pp. 92-122.

3. Dransfield E., Jones R. C. D., and Macfie, H. J. H. (1980) Quantifying changes in tenderness during storage of beef. Meat Sci. 5, 131-137.

4. Geankoplis C. J. (1998) Transport processes and unit operations. Ed. CECSA, Mexico.

5. Igene, J. O. and Pearson, J. M. (1979) Role of phospholipids and triglycerides in warmed-over flavor development in meat model systems. J. Food Sci. 44, 1285-1290.

6. Jung D. S., Kweon, M. R., Auh, J. H., Cho, K. Y., Choi, Y. H., Kook, S. U., and Park, K. H. (1996) Effects of temperature and fluctuation range on microbial growth and quality of foods stored in domestic refrigerator. Korean J. Food Sci. Tech. 28, 632-637.

7. Lagerstedt Å., Enfält, L., Johansson, L., and Lundström, K. (2008) Effect of freezing on sensory quality, shear force and water loss in beef M. longissimus dorsi. Meat Sci. 80, 457461.

8. Pearson, A. M., Gray, J. I., Wolzak, A. M., and Horenstein, N. A. (1983) Safety implication of oxidized lipids in muscle foods. Food Tech. 37, 21-125.

9. Raheliæ S. and Pauè, S. (1985) Structure of beef Longissimus dorsi muscle frozen at various temperatures: 1 . Histological changes in muscle frozen at $-10,-22,-33,-78,-115$ and $-196^{\circ} \mathrm{C}$. Meat Sci. 14, 63-72.

10. Shanks, B. C., Wulf, D. M., and Maddock, R. J. (2002) The effect of freezing on Warner-Bratzler shear force values of beef longissimus steaks across several post-mortem aging periods. J. Anim. Sci. 80, 2122-2125. 
11. Singh R. P. and Heldman, D. R. (2001) Introduction to food engineering. Glascow: Academic Press, pp. 410-446.

12. Wheeler T. L., Miller, R. K., Savell, J. W. and Cross, H. R. (1990) Palatability of chilled and frozen beef steaks. J. Food Sci. 55, 301-303.

13. Witte V. C., Krause, G. F., and Bailey, M. E. (1970) A new extraction method for determining 2-Thiobarbituric acid val- ues of pork and beef during storage. J. Food Sci. 35, 582585.

14. Xu, X., dong, J., Li, T., He, W., and Sun, L. (2013) Influence of storage temperature on lipid oxidation, stale flavor formation and discoloration in Lotus (Nelumbo Nucifera) Bee pollen. J. Food Proc. Preserv. 37, 171-178. 